知識ベースを用いた可変形状トラスの形態および構造解析*1

\title{
Knowledge-Based Approach to Geometric and Structural Analysis of Variable Geometry Trusses
}

\author{
三 木 光 範*2 $・$ 室 津 義 定*3 \\ Mitsunori MiKI, Yoshisada Murotsu \\ 田合 弘 幸*4 \\ and Hiroyuki TAGO
}

Key Words : Knowledgebase, Object-Oriented Approach, Variable Geometry Truss

\begin{abstract}
In order to perform the structural and geometric analyses of variable geometry trusses a knowledgebased approach is adopted. A truss structure is divided into small elements, and their responses are extracted and a knowledgebase is constructed in an objectoriented manner. The object-oriented structural analysis is capable of treating any material and geometric nonlinearlities since the method is based on the iterative relaxation of nodal unbalanced forces by moving the nodes. The object-oriented geometric analysis where a kinematic problem is converted into a problem for a force equilibrium at the nodes is also found to be effective for determining the geometry of variable geometry trusses.
\end{abstract}

\section{1. 緒言}

トラス構造において, 静定構造部分における一部の 部材が能動的にそれ自身の長さを変化させ, それによ って構造全体の形状が変化するものをVGT（Variable Geometry Truss：可変形状卜ラス）と呼ぶ. 従 来, 構造は受動的に力を支え, 形態を保つことがその 基本的機能であった。しかし，こうした能動部材の利 用によって構造はさらに高度な機能を果たすことがで きるようになり，特に宇宙構造の分野で VGT は重要 な位置を占めている( 4)

VGT の挙動を考えるためには形態解析, 構造解析 および振動/動的解析が重要である.ここではこのよ うな解析に新しいアプローチを提案するものであり， その第 1 段階としてこのうち形態解析と構造解析につ

\footnotetext{
*1 平成 7 年 9 月 20 日原稿受理

*2 同志社大学工学部知識工学科

${ }^{* 3}$ 大阪府立大学工学部航空宇宙工学科

*4 大阪府立大学大学院
}

いて考える。

VGT の形態解析は一般に幾何学的な関係を基礎と して部材長とトラスの節点座標に関する非線形の方程 式を求め，それを式(1)のように線型化し，その線型 方程式を繰り返し的に解くことで行われる。

$$
\mathrm{d} X=\frac{\partial X}{\partial L} \mathrm{~d} L
$$

ここで $X$ は節点座標ベクトル．Lは部材長ベクトル である。

一方, 構造解析は有限要素法によって行われるが, 搆造が柔軟な場合変形が大きく，大変形の非線形問題 となりここでも繰り返し計算が必要である.

これらの方法を用いて VGT の解析を行う場合の問 題は次の通りである．第 1 に，部材の材料非線形ちよ びオイラー座屈や薄肉の局所座屈などの部材の力学的 応答の非線形性を考慮するのが容易でない 第 2 に, 能動部材におけるアクチュエータの応答の非線形性を 考慮することが容易でない，第 3 に，そのアクチュエ ータと部材との相互作用を考慮することが容易でな い第 4 に, 不静定トラス構造における形態解析がで きない、ことである。このうち，最後の点について は，不静定構造では部材長と節点座標の間に 1 対 1 の 関係が無く，部材の変形を考慮しなければならないこ と，すなわち，形態解析と構造解析がカップリングし ていることに起因する。一方, 他の 3 点は，種久の複 雑な非線形性を考慮するためには通常の構造解析手法 に多くの複雑な付加的方法を加える必要が有ること, そのような解析の搪張は一般に多くの労力を必要とす ることに起因する．

こうした問題は極めて軽量かつ柔軟に作られた宇宙 構造用の VGT では無視できない問題である.ここで はこうした問題を解決するための方法として分散問題 
解决のアプローチを採用し，知識ベースシステムを用 いてそれを貴体化する方法を提案する。

\section{2. 分散問題解決と知識ベース}

分散問題解決とは, ある特定の問題を解く作業を複 数のモジュール間で分割し，問題と問題の展開に関す る知識を各モジュールが分割/共有し, 相互に協力し てその問題を解く方法を指す5). 重要なことは, 全体 としての大きな問題を解く方法に関する知識は明示的 には無く, 問題がより小さな部分問題に分割され，そ してその部分問題を解く知識が起動され, それら部分 問題の解の集合あるいは統合として全体の問題が解決 される点である。こうしたアプローチは生物が持つ問 題解決能力と似ており, その有用性は最近多くの分野 で示されているの）後に詳しく述べるが，ここでは各 モジュール固有の知識が記述されているのみで, 構造 解析と形態解析のための明示的な知識は存在しない

分散問題解決では各モジュールが明示的な知識，す なわち主として宣言的な知識表現を有していることが 重要な点である.ここではトラス構造物は階層的な要 素集合に分解され，各要素固有の知識が抽出された。 それらの知識は要素の本質的な挙動を規定する知識で あり，トラスの形態および構造解析には直接関係のな い知識である．この点は極めて重要である．解析のア ルゴリズムを知識として記述した場合には目標とする 解析は可能でも，異なった挙動の解析は不可能であ る.ここでは線形解析, 非線形解析, 形態解析, 構造 解析などに関係なく要素固有の知識を考えた．

分散問題解決のアプローチでは複数のモジュールが 部分問題を解決するための知識ベースを有している. 知識ベースを構築する方法にはいくつかの方法》があ るが、最近ではオブジェクト指向モデルが注目を集め ている，そこでは，対象を階層構造を持つクラスのイ ンスタンスとして考え, そのオブジェクトにメッセー ジを送信することによってアクションを生起させる。 知識はクラス階層構造とメッセージによって起動され るアクションすなわちメソッドによって記述される. オブジェクト指向における知識は構造を持った知識で あり，このため対象のモデル化が容易で，大規模の知 識が容易にモジュール化でき，プロダクションシステ ムと比較して処理効率は高い また, オブジェクト指 向は複雑度の高いシステムを理解し, 解析し，そして 設計するための方法論として極めて有用である ${ }^{8)}$.

構造や制御の分野におけるオブジェクト指向の方法 論の応用については複合材料の力学的解析 ${ }^{9}$, はりの 変形解析 ${ }^{10)}$, トラス構造解析 ${ }^{11)}$. 物理量の処理 ${ }^{12)}$, 最 適化 ${ }^{13)}$, VGT の運動コントロール ${ }^{14)}$, および運動方
程式導出システム15) などの研究があるが、VGT の形 態解析と楧造解析を統合した研究はない.

本研究で対象とするVGTはすでに述べた種々の非 線形性を考慮する観点から考えると複雑なシステムで あり、こうしたシステムに関わる知識を記述するため にはオブジェクト指向の持つ優れたモデル化能力が重 要となる．そして階層的に表現されたオブジェクト と, 複数のオブジェクトを集約してモデル化される高 機能のオブジェクトの集合が，それぞれに固有の知識 を起動させながら問題解决を行うオプジェクト指向の アプローチが最も適したものと考えられる。重要な点 は，各オブジェクトを可能な限り正確に記述すること により，全体の問題は自然な形で分割され，階層的な 部分問題に変換され, 最下位のレベルでの問題解決方 法が記述されていれば全体の問題が自然に解けるとい う点である。

\section{VGT のオブジェクト指向モデル化と分散知識}

3.1 トラス構造のモデル化と分散知識 トラス構 造は節点, 部材，および支持からなる，各節点は座 標，支持，それに結合している部材などのデータを有 している，各部材は材料，断面形状，長さ，両端の節 点などのデータを有している，支持は回転支持と可動 支持に分類され，可動支持はさらに水平可動支持と垂 直可動支持に分類される. 各材料は名称, 弾性定数, 強度などのデータを有している。断面形状は円断面や 矩形断面などに分類される。このような静的な知識は 第 1 図に示すクラス階層構造と第 1 表に示すインス夕 ンス変数で表されるオブジェクトの集約化によって表 現される。

第 1 図においては，字下げはスーパークラスとサブ クラスの関係を表しており．字下げしたものは上のク ラスのサブクラスである．たとえば支点クラスは回転 支点クラスと可動支点クラスをサブクラスとして有

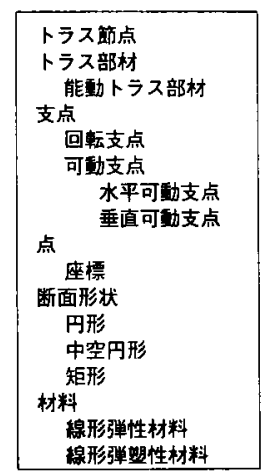

第 1 図 トラス構造のクラス階層構造 
し，可動支点クラスは水平可動支点と垂直可動支点ク ラスをサプクラスとして有する。なお，点クラスは Smalltalk 言語に標準で備わっているクラスであり， 内部状態として $x$ 座標と $y$ 座標を有する.

メッセージに対応する応答としての知識は各クラス におけるメソッド(これは Smalltalkにおける用語 である。C+十ではメンバ関数と呼ばれる）として記 述される。それらのメソッドはそれぞれのクラスに扔 ける固有の知識である。トラス節点扔よびトラス部材 の各クラスにおける代表的なメソッドを第 2 表に示 す

3.2 能動部材のモテル化と分散知識 能動部材は 部材の中にアクチュエータを有しており，その作用に よって部材の長さが変化する。アクチュエータは基本 的に，力を発生させるものと変位を発生させるものが ある。いずれのアクチュエータも部材力との相互作用 で非線型挙動が変化する可能性がある，また，限界の 荷重を越えると動作しない，あるいは耐荷重性を失う

\begin{tabular}{|c|c|c|}
\hline クラス & インスタンス変数 & $\begin{array}{c}\text { 変数の内容 } \\
\text { (インスタンスのクラス名) }\end{array}$ \\
\hline トラス & $\begin{array}{l}\text { 節点群 } \\
\text { 部材群 }\end{array}$ & $\begin{array}{l}\text { トラス節点群 } \\
\text { トラス部材群 }\end{array}$ \\
\hline トラス節点 & $\begin{array}{l}\text { 座標 } \\
\text { 支持 } \\
\text { 部材群 } \\
\text { 反力 } \\
\text { 外力 } \\
\text { 節点不平衡力 }\end{array}$ & $\begin{array}{l}\text { 座標 } \\
\text { 支持 } \\
\text { トラス部材群 } \\
3 \text { 次元力 } \\
3 \text { 次元力 } \\
3 \text { 次元力 }\end{array}$ \\
\hline トラス部材 & $\begin{array}{l}\text { 材料 } \\
\text { 断面形状 } \\
\text { 初期長さ } \\
\text { 節点 } 1 \\
\text { 節点 } 2 \\
\text { 部材力 } \\
\end{array}$ & $\begin{array}{l}\text { 材料 } \\
\text { 断面形状 } \\
\text { 数値 } \\
\text { トラス節点 } \\
\text { トラス節点 } \\
1 \text { 次元力 } \\
\end{array}$ \\
\hline 能動トラス部材 & アクチュエータ & アクチニエータ \\
\hline
\end{tabular}

など、アクチュエータの種類に応じて複雑な特性があ る、これらを正確にモデル化した．第 2 図はアクチュ エータを持つ部材とアクチュエータのモデル化であ りアアクチュエータ部分以外の部材の座屈などを評価 するために部材はアクチュエータ両側で固有の長さを 有している。なお，(a)のクラス階層構造において は，字下げはスーパークラスとサブクラスの関係を表 しており．字下げしたものは上のクラスのサブクラス である。

アクチュエータは変位制御型と力制御型に分かれ， 内部状態として変位, 軸力, 変位下限值, 変位上限 値, 荷重下限值, 荷重上限值, 破損荷重, 目標変位 （力）および変位（力）速度を持つ変位制御型アク チュエータの動作は次のとおりである。まず,アクチ

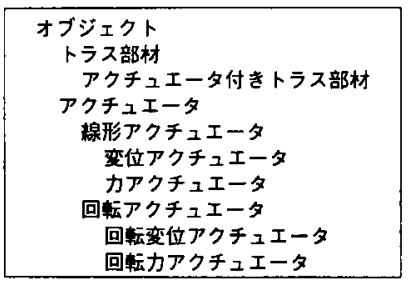

（a）トラス部材とアクチュエータのクラス階層構造

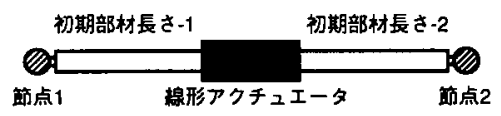

（b）アクチュエータのモデル化

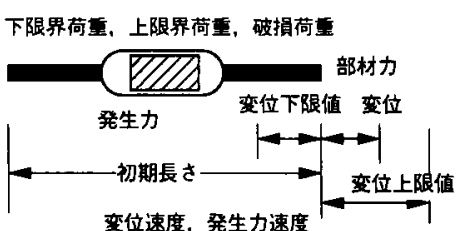

(c)

第 2 図 アクチュエータを持つ部材とアクチュエータのモ デル化

第 2 表 トラス構造に関するクラスのインスタンスに有効なメソッド

\begin{tabular}{|c|c|c|}
\hline メッセージ送信先 & メッセージ & メッセージに対する応答 \\
\hline \multirow[t]{3}{*}{$\begin{array}{l}\text { トラス節点クラスの } \\
\text { インスタンス }\end{array}$} & 節点力を求めよ & $\begin{array}{l}\text { 接続部材から部材力を受け取り,それらと外 } \\
\text { 力および節点反力との和を求める }\end{array}$ \\
\hline & $\begin{array}{l}\text { 節点力の節点変位に対す } \\
\text { る感度を求めよ }\end{array}$ & 節点力の節点変位に対する感度を求める \\
\hline & 平衡位置に移動せよ & 節点不平衡力が 0 になる推定位置に移動する \\
\hline \multirow{3}{*}{$\begin{array}{l}\text { トラス部材クラスの } \\
\text { インスタンス }\end{array}$} & 与えられた節点に関する & 与えられた節点に関する自節点からの方向を \\
\hline & 方向を求めよ & 計算する \\
\hline & 部材力を計算せよ & 部材力を計算する \\
\hline
\end{tabular}


エエータには目標変位が与えられる。アクチュエータ は目標変位と現在の変位を一致させる方向に伸縮する が，部材力が荷重限界を越えると動作は停止する。ま た，部材力がアクチュエータの破損荷重を越えると荷 重保持力はなくなる.

部材とアクチュエータのこのような非線形挙動がト ラス解析に正確に反映されるために，外部負荷とアク チュエータの動作の時間的順序，あるいは複数のアク チュエータが存在する場合のそれらの動作順序の追跡 は極めて重要な問題である．なぜなら，非線形システ ムでは最終状態は同じでも異なる負荷経路で生じる結 果は異なるからである．ここでは時間的順序について は大域的な時計を設定し，微少時間ごとの各アクチュ エータの変位の発生を繰り返すことによって全体挙動 を追跡する。この繰返し中にアクチュエータの過荷重 による動作停止が生じた場合には 1 ステップだけ時間 を戻し，それが停止する時刻を二分法を用いて正確に 評価し，その時点から再度同様の繰返しを始める，部 材の塑性挙動や座屈挙動なども同様にして追跡でき る、構造解析はこうした繰り返しの各ステップごとに 実行される。

3.3 幾何学的対象および物理量のモテル化と分散 知識座標と断面形状のクラス階層構造は第 1 図に 示されている. 座標は Smalltalkの有するクラス Pointのサブクラスとして設計し，それが持つ種々の メソッドを再利用する. 一方, 断面形状は構造力学に おいて必要となる断面積, 断面 2 次モーメント，図 心，あるいは中立軸などの属性に関する知識を保持し ている．また，長さ，質量，力，あるいは応力といつ た工学的物理量についてもモデル化を行い, 演算や変 換に関する知識を埋め込む。

\section{4. 形態解析と構造解析の統合}

VGT の形態解析と構造解析を統合するには，従来 用いられている幾何学的方程式と全体剛性方程式を用 いるのではなく，能動部材が長さを変化させたときに 生じる現象をモデル化することが必要になる．幾何学 的方程式は現象の本質ではなく，結果として生じる状 態の関係を表現したものに過ぎず，VGTの形状は力 によって変化させられる。この観点から, 形態解析と 構造解析は容易に統合できる。すなわち，能動部材の 長さが変化すると部材両端の節点には力が発生し, 節 点は力の平衡がとれる位置に移動する。もし外部負荷 がなければ移動後の座標は幾何学的方程式を満足して いる. 外部負荷が存在すれば幾何学的方程式と全体剛 性方程式が同時に満足される位置に移動する。こうし て VGT の形態解析と構造解析は完全に統合される.
重要な点は, 形態解析と構造解析は全体からの視点 ではまったく異なった方程式によって支配されている が，節点という局所的な視点では何の区別も無い現象 から生じて抢り，局所的な現象のモデル化によって両 者は統合できるということである．こうした概念は分 散問題解決のアプローチの優位性を示している.

上の議論で形態解析と構造解析は節点における力の 平衡という一つの単純な現象を積み上げれば行えるこ とがわかった。すなわち，「ある質点の加速度はその 質点に作用する外力の合力に比例し，その質点の質量 に反比例する」というニュートンの運動法則の第 2 法 則という知識から導かれる「力は静的状態で平衡条件 を満足する」という知識は「静的条件においてトラス の節点で力は平衡を保つ」ことと等価であり，その宣 言的知識を基に，平衡条件が崩れた場合の変化を「節 点に負荷される複数の力が存在し，その合力が 0 でな い場合、節点はその不平衡力が 0 になる位置に移動す る」という操作的知識に変換することによって追跡す ることが可能になる。

平衡条件の満足のために節点が移動する知識は節点 オブジェクトの知識として記述される。すなわち，卜 ラス構造に平衡条件を満足せよというメッセージが送 られたとき，トラス構造から各節点には平衡位固に移 動せよというメッセージが送信される。このとき節点 オブジェクトでは移動のための知識が起動される。そ の知識は第 3 図のように記述されている.

これは、「手続き 1 ：その節点における節点力の節 点変位に対する感度を求めよ」，「手続き $2:$ その節点 に扔ける節点力（不平衡力）を求めよ」，「手続き 3 ： その感度の逆行列を求め, 節点力と乗算し, 節点移動 量を求めよ」，「手続き 4 ：現在の座標に節点移動量を 加え，新しい座標とせよ」という4つの手続きからな っている，手続き 1 のために感度を求めるメッセージ (forceSensitivity) が自身（self）すなわち節点に送 られ，感度解析のための知識が起動される，手続き 2 では自身（self）すなわち節点に節点力を求めるメッ セージ (nodalForce) が送信され，節点オブジェク トの中の知識が起動される. 手続き 3 では, 節点力感

Method: moveToBalancePoint
torceSensitivity $:=$ self forceSensitivity.
nodalForce $:=$ self nodalForce.
displacement $:=$ (forceSensitivity inverse)
productOnVector3D: nodalForce negated.
$\wedge$ coordinate $:=$ coordinate + displacement

第3図 節点オブジェクトにおける移動のための知識 (Smalltalk 言語による記述) 
度オブジェクト（forceSensitivity）に逆行列を求め るメッセージ (inverse) が送信され，それはスーパ ークラスであるマトリックスオブジェクトでの知識を 起動する、マトリックスの演算に関する知識はマトリ ックスオブジェクトに記述される，そして得られた節 点変位感度オブジェクトに節点力オブジェクトの乗算 が依頼（productOnVector3D）され，これは節点変 位感度オブジェクトのスーパークラスであるマトリッ クスオブジェクトでのベクトルとの乗算に関わる知識 を起動する。なお，節点力には負符号をつけるメッセ ージ (nagated) が送信され，この力と釣り合うため の変位が求められることになる．手続き 4 では，こう して得られた移動べクトル（displacement）を節点 座標ベクトルに加えるメッセージ $(+)$ を座標オブジ エクトに送る。ベクトルの演算に関する知識はべクト ルオブジェクトに記述される。

一方, 当該節点における節点力の節点変位に対する 感度を求めるメソッドでは，その節点が座標軸の各方 向に微小量移動することにより得られる節点力の変動 を基に感度行列が構成される.この場合, 当該節点以 外の節点の移動量は未定であるからそれらを0として 感度を求める。このため, 実際には各節点は移動し, 節点力は 0にはならない このため，収束のための繰 り返し計算が必要になる。また，この感度から得られ る節点移動量は幾何学的にも材料の応答においても線 型推定量であるため，この点からも収束のための繰り 返し計算が必要になる。

な掠，前者の繰返し計算は連立1次方程式の Gauss-Seidel 法による解法と原理的には同じであり， 収束は保証されている。一方，非線形に関する絽返し は収束は保証されておらず，発散する場合には繰返し 計算における増分を十分小さな值に調節する必要があ る.

こうして，知識は極めて明示的に記述され，しかも その知識は適切なクラスに格納され, 合理的な階層構 造を有していることがわかる。

注意する必要があるのは複数のアクチュエータが存 在する場合，その同期の問題である. 非線形解析にお いては変化の経路によって最終状態が変化する.した がって，複数のアクチュエータが動作する場合，その 動作が意図している同期状態を正確に模擬しなければ ならない.すなわち, 各アクチュエータの動作速度と 動作時刻から伸縮の微小ステップ幅を調整し, そのス テップ毎に構造解析を繰り返して同期をとることにし た。これによって、アクチュエータと部材力との相互 作用，すなわち，アクチュエータは過負荷により停 止，もしくは破椇する現象が解析できる。

\section{5. 知識ベースシステムの開発と実行結果}

ここでの解析システムの構築にあたっては, 計算機 として SunSPARCStation SS-10 TX-4 を用い, 知識 ベースの記述には Smalltalk（Visual-Works/Smalltalk）を用いた。開発した知識ベースにおいてここで の解析に直接必要となるクラス数は約 30 ,メソッド 数は約 280 である。
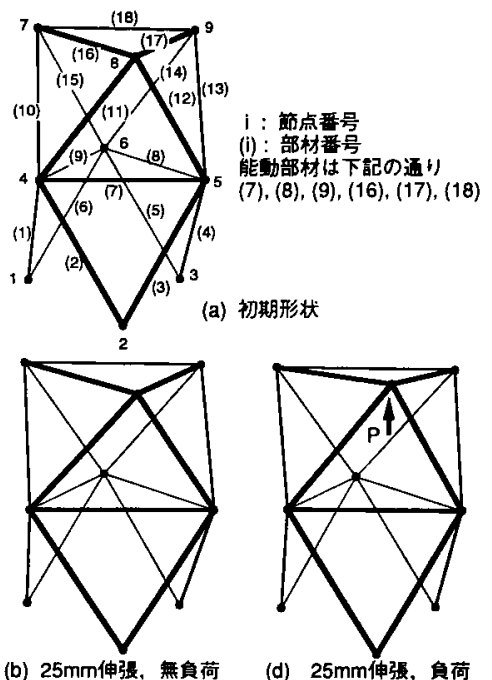

(b) $25 \mathrm{~mm}$ 伸張，無負荷

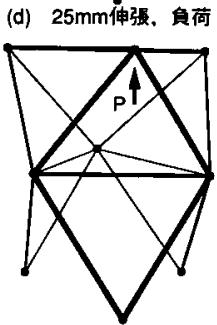

（c） $50 \mathrm{~mm}$ 伸張，無覥荷

(e) $50 \mathrm{~mm}$ 伸㡎、角荷

第 4 図 3 次元 VGT の解析結果
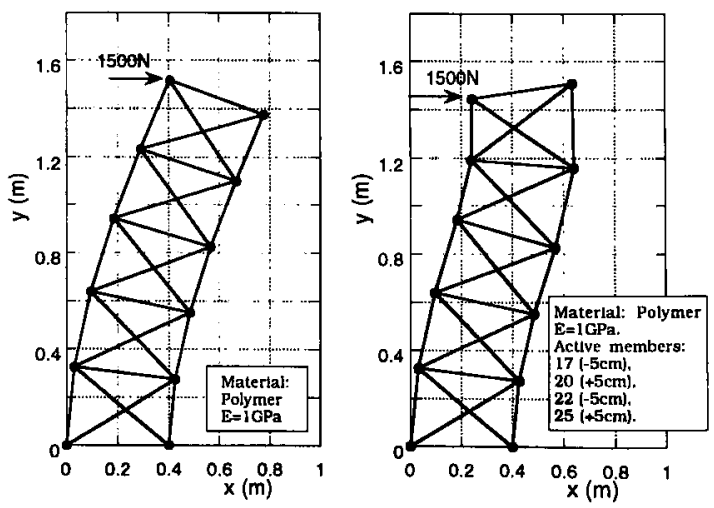

第 5 図 構造解析と形態解析の統合化 
第 4 図は，アクティブ部材を 6 本有するOctahedoron type の 9 節点 3 次元 VGT の解析結果を示 したものである。ここで，組み込まれたアクチュエー 夕は変位型のもので, 作動限界荷重は $5 \mathrm{kN}$ である. 図中，（a）は初期形状を示し，各部材の長さは 200 mmであり，(b)はすべてのアクチェエータを 25 $\mathrm{mm}$ 変位させたもの，(c)はすべてのアクチュエータ を $50 \mathrm{~mm}$ 変位させたものである。いずれも無負荷で あり，この結果は形態解析が提案手法で行えることを 示している。一方，(d)および(e)は図に示す荷重を 作用させてからアクチュエータを同様に $12.5 \mathrm{~mm}$ お よび $25 \mathrm{~mm}$ 変位させたもので,この場合には部材 7 のアクチュエータか゚ $7.5 \mathrm{~mm}$ 変位したところで軸力が 限界荷重を越えて動作を停止した（b)と（d）および (c)と (e)の結果を比較すると, 部材 7 のアクチュエ 一タが伸び切れないことがわかる。アクチュエータの 伸びによるこうした部材力の変化は形状の変化による 非線形性に起因するものである。

一方，第 5 図は不静定トラス構造にアクチュエータ 部材を組み込み、構造解析と形態解析を同時に行った 結果で，左側の図ではアクチュエータは作動しておら ず，右側の図では下から 4 および 5 段目の左右の部材

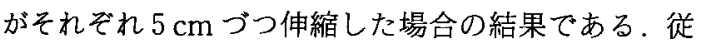
来の方法ではこのような不静定トラス構造の形態解析 は行えなかった。一般には, 不静定トラス構造にアク チュエータ部材を組み込んで大きな変形を生じさせる ことは困難であるが，負荷された荷重の伝達経路をあ る程度変化させることにより, 破損した部材の荷重を 減少させるなどの能動性を発揮できるものと思われ， 新しい考え方として検討する洒值がある．

これらの結果より，VGTにおいて従来なされてい なかった形態解析と構造解析の統合化が行え,さらに は，その統合化によってアクチュエータの動作停止な ぞを含む複雑な挙動と部材の軸力との相互作用が容易 に解析できることがわかる。

\section{6. 考察}

6.1 機能と知識との関係 ここでオブジェクトと して考えたものは物理的な要素であり，その要素の入 出力関係が知識として記述されている。これは知識と 呼ぶより機能といった方が適切ではないかという議論 が有るかもしれない. 従来知識として一般的に考えら れたものは物理現象における入出力ではなく，人間の 判断に基づく，より高度な知識を考えてきた した観点からすれば，材料に力が作用したときのひず みは知識によって記述されるべきものではなく，むし ろ機能として関数を用いて記述する方が良いのではな
いかという考え方もある。しかしながら，次に示す観 点から我々は物理的要素に関しても知識表現で記述す るメリットは大きいと考える。一つは，知識の表現が 明示的になること，一つは知識の追加や更新が容易で あること，そして最後に物理現象に関する入出力とい えども人間がある観点で切り取った恣意的な部分を含 むまさに “知識”であること，であるからである．問 題は効率であり。しかもその効率は最初のモデル化に 始まって解析方法の定式化，コード化，そして結果を 得るまでに支払うコストが一つの判断基準となる。こ うした観点からも物理的要索の複雑な久出力を明示的 な知識として記述することの利点は多いと考える。

6.2 知識ベースを用いた分散問題解決の優位性と 問題点 ここで提案した方法によって複雑な挙動を 示すVGTの形態解析と構造解析の統合化が行え，提 案手法は有効であることがわかった。この方法の利点 は，1）様々の非線形性，および連成現象を容易に解析 できる，2）知識べースにおける知識が明示的に記述さ れており, 知識の追加および変更が容易である点であ る.これらの点はすでに明らかであるが，ここでは材 料非線形性に関する知識の追加を行って，再度検証を 行う

前述した実行結果ではトラス部材の材料は線型弾性 体であった。この場合，応力とひずみに関する知識は 第 3 表(a)のように記述されている.もし弾塑性材料 を用いる場合には第 1 図に示したクラス階層構造にお いて, 材料のサブクラスとして弾完全塑性材料のクラ スを作成し，その材料の一つのメソッドとして第 3 表 (b)に示す応力とひずみに関係する知識を記述する. そして，VGTの生成においてそのクラスを使用する だけで，あとは何の変更もなく非線形材料に関する解 析が行える。すなおち，全体の知識ベースの一部，し かも構造化されて適切に格納されている知識の一部に 簡単な知識を追加するだけで良いことがわかる。こう したことは異なった材料を用いる場合, 複雑な挙動を 有する材料を用いる場合，あるいは材料の熱膨張を新

第 3 表 応力とひずみに関する知識 (a) 線形弾性体

\begin{tabular}{|c|c|}
\hline メッセージ & 応力を求める(引数：ひずみ) \\
\hline 応 答 & (維弾性定数×ひずみ)を返す \\
\hline \multicolumn{2}{|c|}{ (b) 弾完全塑性体 } \\
\hline メッセージ & 応力を求める(引数：ひずみ) \\
\hline 応 答 & $\begin{array}{l}\text { もし, ひずみが引張降伏ひずみより } \\
\text { 大きいなら, 引張降伏応力を返す } \\
\text { もし, Uずみが縮降伏ひずみより } \\
\text { 小さいなら, 厌縮降伏応力を返す }\end{array}$ \\
\hline
\end{tabular}




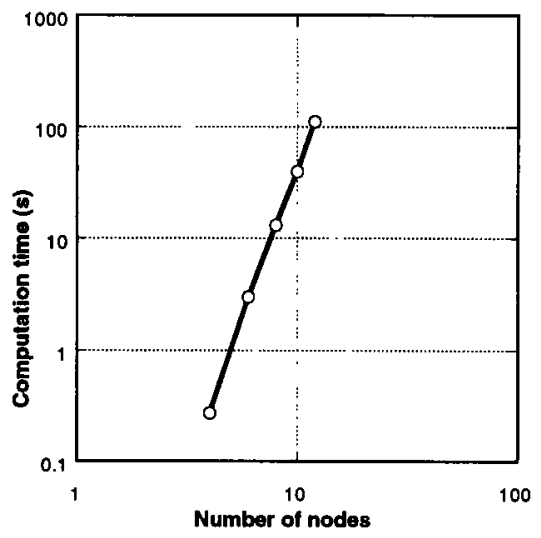

第 6 図 2 次元トラス構造の節点数と構造解析の計算時間 の関係

たに考虑する場合などにも同様である．

一方，提案手法の問題点は，1)計算時間が長い，2) クラス階層構造を適切に作成するのは容易でない場合 があることである．前者については後で考察する．後 者については，これはオブジェクト指向アプローチに 普遍的な問題である.この方法がルールベースに比べ て高速で大規模な処理と知識の体系的把握が容易であ る利点はこのクラス階層構造にあり，適切なクラス階 層構造をある程度の時間をかけて作成する必要がある のはやむを得ないことである．むしろこうした構造 を考えることによって人の頭にある知識の明確化が促 進される利点があり、これは問題点とは考えない方が よいと思われる。

知識ベースシステムでは知識の検索が行われている ため, 処理速度は遅い 特に,ここで使用した Smalltalk は計算機上でのコードモジュール（実行可能な 機械語コード）を生成する言語ではなく，中間コード を生成し，それをインタプリタ（解釈実行系）で実行 するためさらに速度が遅くなる．第 6 図梳 2 次元卜ラ ス構造の節点数と構造解析にかかる計算時間の関係を 示したもので，計算時間が節点数の約 5 乗に比例して 増大していることがわかる。このため，使用する計算 機はできるだけ高速のものを用いる必要がある．ま た，これ以上の速度を求める場合には使用する言語は Smalltalkではなく，オブジェクト指向言語として最 近よく用いられているC++が望ましいこの言語で は完全なロードモジュールが生成され，処理は高速と なる。

\section{7. 結論}

形状可変トラス構造における形態解析と構造解析を
統合し，材料非線形，構造非線形，アクチュエータの 非線形応答性, そしてアクチュエータと部材力との相 互作用などの複雑な現象を容易に解析する目的で知識 ベースを用いた分散知識処理のアプローチによる新し い方法を提案し，次の結論を得た。

VGT を構成するすべての要素をオブジェクトとし て捉え, それらの階層構造を考え, 各オブジェクトに 固有の知識を抽出し, 知識ベースを構築することがで きた。

節点における力の平衡という知識が構造解析と形態 解析を統合することを明らかにし，こうした分散問題 解決のアプローチが多くの非線形現象を付加的な知識 なしに解決することを明らかにした。

構築された知識ベースと分散問題解決のアプローチ を基にいくつかの解析を行い，提案手法は有用である ことがわかった。また，提案手法は柔軟な知識の追加 によってさらに複雑な問題にも容易に対処できること がかかった。

構造解析と形態解析の統合により、アクチュエータ と部材力との相互作用を容易に評価することができ， また，不静定の構造に対してもこうした統合解析がて きることを示した。

\section{参考文献}

1) Miura, K. and Furuya, H. : Adaptive Structure Concept for Future Space Applications, AIAA J., 26 (1988), pp. 995-1002.

2) Wada, B. K. and Utku, S. : Adaptive Structures for Deployment/Construction of Structures in Space, Proceedings of the 33rd AIAA/ASME/ASCE/AHS/ASC Structures, Structural Dynamics and Materials Conference, AIAA, 1992, pp. 379-395.

3) Chen, F.S. and Wada, B. K. . On an Adaptive Truss Manipulator Space Crane Concept, Proceedings of the First Joint U.S./Japan Conference on Adaptive Structures, Wada, B. K., Fanson, J. L. and Miura, K., eds., 1991, pp. 726-742.

4) Murotsu, Y., Senda, K. and Hisaji, K. : Optimal Configuration Control of an Intelligent Truss Structure, Proceedings of the First Joint U. S./Japan Conference on Adaptive Structures, Wada, B.K., Fanson, J. L. and Miura, K., eds., 1991, pp. 157-175.

5) Bond, A. H. and Gasser, L. (eds.): Reasings in Distributed Artificial Intelligence, Morgan Kauffmann Pub., San Mateo, 1988, p. 3.

6) Manner, R. and Mandrick, B. (eds.): Parallel Problem Solving from Nature, Elsevier Science Pub., Amsterdam, 1992, p. 2.

7）上野晴樹，石塚 満：知識の表現と利用，オーム社，東京, 1987, p. 7.

8) Booch, G.: Object-Oriented Analysis and Design with Applications, The Benjamin/Cummings Pub. Co., Redwood, 1994, p. 3.

9) 三木光範，杉山吉彦：オブジェクト指向による複合材料の力 学的解析, 日本機械学会論文集, 56, 527-A (1990), pp. 1648- 
1653.

10) 三木光範, 杉山吉彦, 内田雄治 : オブジェクト指向によるは りの変形解析, 日本機械学会論文集，57，541-A (1991)，pp. 2154-2159.

11) 三木光範, 杉山吉彦, 内田雄治 : トラス㧛造解析, 日本機械学 会論文集, 57, 541-A (1991), pp. 2160-2165.

12）三木光範，杉山吉彦，内田雄治：オプシェクト指向による構 造工学における物理量の処理，日本機械学会論文集, 57, 543A (1991), pp. 2830-2835.

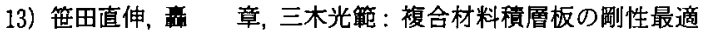
化エキスパートシステムの開発，日本機械学会論文集， 58 ,
551-A (1992), pp. 1175-1180.

14) Huang, S., Natori, M., Miura, K., Nakai, S. and Katsukura, H.: An Object-Oriented Approach to the Motion Control of a Free-Froating Variable Geometry Truss, Proceedings of the AIAA/ASME Adaptive Structures Forum, AIAA, 1994, pp. 465-473.

15）藤井裕矩，武田重之：オブジェクト指向言語を用いた多体柔 軟宇宙構造物の運動方程式導出システム, 日本航空宇宙学会 誌, 43 (1995), pp. 143-152. 